症例

\title{
単孔式腹腔鏡下胆囊摘出術を施行した手術既往のある胆囊結石の 3 例
}

\author{
水戸赤十字病院外科 \\ 清 水 芳 政 鈴木 和光 関 太要 \\ 小澤陽介立川伸雄捨田利外茂夫
}

\begin{abstract}
手術既往のある胆囊結石症例に対し，単孔式腹腔鏡下胆囊摘出術を 3 例に実施した. 症例 1 は開腹胃切除と帝王切開と虫垂切除, 症例 2 はCrohn 病に対し腹腔鏡補助下回盲 部切除㧍よびイレウスに対し腹胫鏡補助下癒着剥離小腸部分切除, 症例 3 は開腹胃切除 の既往があった，症例 1,2 は臍周囲および上腹部に広範な癒着を認めた。 まず, 直視 下に臍周囲の癒着を剥離しマルチチャンネルポートを装着, 次いで, 腹腟鏡下に上腹部 と胆囊周囲の癒着を剥離し胆囊を摘出した. 症例 3 は術中胆囊動脈の損傷による出血をき たしたが，臍部ポートからのガーゼの出し入れを迅速に行い出血部を視認し止血した.

単孔法は従来法や細径法と比較し技術的難易度が高い. しかし, 臍部の癒着を直視下 に剥離することや, 最小限の剥離範囲で胆囊に到達でき, 出血などの合併症においては ポートの脱着によりガーゼや止血剤の出し入れが容易に行え, 緊急時への対応にも優れ ていると考えられた.
\end{abstract}

索引用語：単孔式腹腔鏡下胆囊摘出術, 手術既往, 胆囊結石

はじめに

1990年に本邦で初の腹脘鏡下胆囊摘出術（laparoscopic cholecystitis，以下 LC) が施行され，30年弱 が経過し今や胆囊結石症に対する標準術式となって久 しい.さらに，低侵襲性と整容性向上のため単孔法や 細径法といった reduced port surgery（以下，RPS） が開発され，胆囊摘出術においても各施設で導入が試 みられている。一方, 急性胆囊炎や上腹部開腹手術既 往例などに対しLCを第一選択としている施設は未だ 4 割弱にすぎない1).今回われわれは手術既往のある 胆囊結石症 3 例に対し, 単孔式腹腔鏡下胆囊摘出術 (single incision laparoscopic cholecystectomy, 以下 SILC）を施行しえたので報告する.

\section{症 例}

症例 $1: 75$ 歳, 女性.

主訴: 右季肋部痛.

既往歴：20歳台に帝王切開, 30歳台に虫垂切除術, 60 歳台に胃癌に対し開腹幽門側胃切除 B- I 再建を施

2018年 3 月27日受付 2018 年 6 月15日採用

〈所属施設住所〉

₹ 310-0011 水戸市三の丸 $3-12-48$
行されていた。

家族歴：特記事項なし。

現病歴：食後に右季肋部を自覚するようになり, 近 医を受診した，腹部エコー検査にて胆囊結石が指摘さ れ，当院紹介受診となった。

初診時現症 : 身長 $148 \mathrm{~cm}$, 体重 $53 \mathrm{~kg}$. 腹部は平坦 · 軟で, 右季肋部に軽度の圧痛を認めた。

検査所見: 血液生化学検查では, 肝胆道系酵素の上 昇や炎症反応の上昇は認めなかった。腹部超音波検査 にて $8 \mathrm{~mm}$ 以下の結石を多数認めた. DIC-CTにて総 胆管結石抢よび胆囊管の分岐異常は認めなかった (Fig. 1a).

手術所見：臍を右に避ける上下腹部正中切開創を有 していた（Fig. 1b）。臍部に約 $2.5 \mathrm{~cm} の$ 縦切開を置き 小開腹した，臍直下の癒着を直視下に剥離しラッププ ロテクター ${ }^{\circledR}(\mathrm{HAKKO})$ を留置し， 2 本の $5 \mathrm{~mm} \mathrm{EZ}$

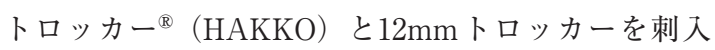
したEZアクセス ${ }^{\circledR}(\mathrm{HAKKO})$ を, ラッププロテクタ 一に装着した。 スコープは $12 \mathrm{~mm}$ オリンパス軟性鏡を 用いた，腹壁に大網と横行結腸が癒着しており，超音 波凝固切開装置を用い剥離を進め胆囊底部を見出し た。さらに, 胆囊に癒着した大網および十二指腸を剥 

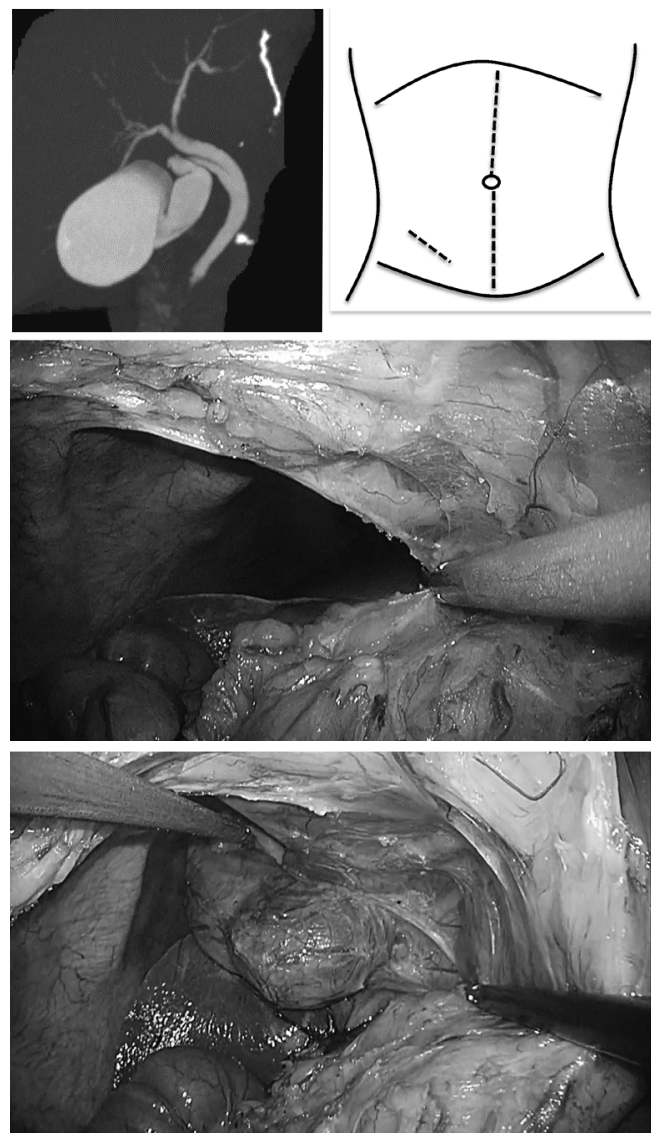

Fig. 1a：DIC-CT所見. 明らかな総胆管結石や胆囊 管走行異常は認められない.

b : 臍を右に避ける上下腹部正中切開創および 右下腹部斜切開創を有していた。

$\mathrm{c}$ ：上腹部正中切開層に大網と横行結腸の癒着 を認めた。

$\mathrm{d}$ ：必要最小限の剥離により胆囊に到達した。

$$
\frac{\mathrm{a} \mid \mathrm{b}}{\mathrm{c}}
$$

離し胆囊の全貌を展開した。胆囊床から順行性に剥離 を進め胆囊動脈, 胆囊管をクリッピングし胆囊を摘出 した. 手術時間は76分, 出血量は $10 \mathrm{~g}$ であった（Fig. lc, d).

術後経過：術後 4 日目に軽快退院した.

症例 $2: 52$ 歳, 男性.

主訴：右季胁部痛.

既往歴：20歳台にCrohn病に罹患, 30歳台に腹腔鏡 補助下回盲部切除, 1 年前に腸閉塞にて腹腔鏡補助下 癒着剥離，小腸部分切除術を施行されていた.

家族歴：特記事項なし.
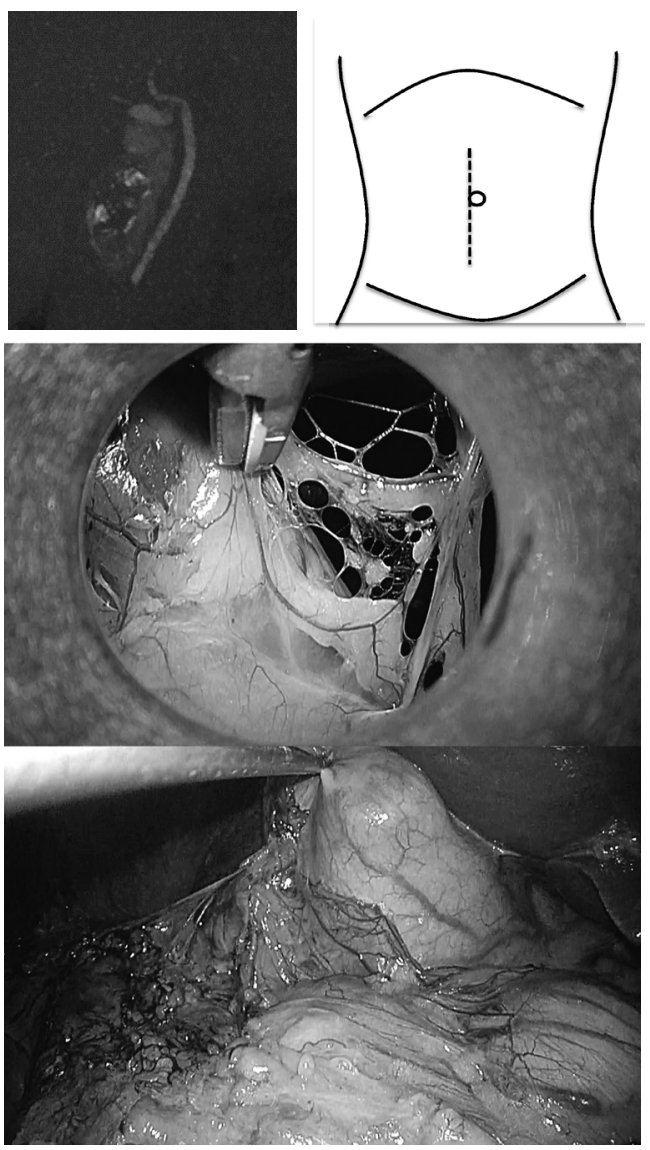

Fig. 2a：DIC-CT 所見. 明らかな総胆管結石や胆囊 管走行異常は認められない.

b : 臍を左に避ける中下腹部正中切開創を有し ていた.

c：マルチチャンネルポートを留置した直後で あり, 臍周囲に大網と横行結腸の強固な癒着を認 めた.

$\mathrm{d}$ : 右上腹部にも癒着を認めたが, 必要最小限 の剥離により胆囊に到達した。

$$
\frac{\mathrm{a} \mid \mathrm{b}}{\mathrm{c}}
$$

現病歴：食後に右季肋部を自覚するようになり，当 院内科を受診した。

初診時現症：身長 $179 \mathrm{~cm}$, 体重 $70 \mathrm{~kg}$. 腹部は平坦・ 軟で，右季肋部に圧痛を認めた.

検査所見：血液生化学検査では，炎症反応の上昇は 認めなかったが肝胆道系酵素の著明な上昇を認めた。 WBC $5,920 \times 10^{3} \mu \mathrm{L}$, AST $426 \mathrm{U} / \mathrm{L}$, ALT $714 \mathrm{U} / \mathrm{L}$, ALP 394U/L, $\quad \gamma$-GTP 383U/L， 総ビリルビン 2.88 $\mathrm{mg} / \mathrm{dl}$, CRP $0.05 \mathrm{mg} / \mathrm{dl}$ であった. 腹部超音波検査に 

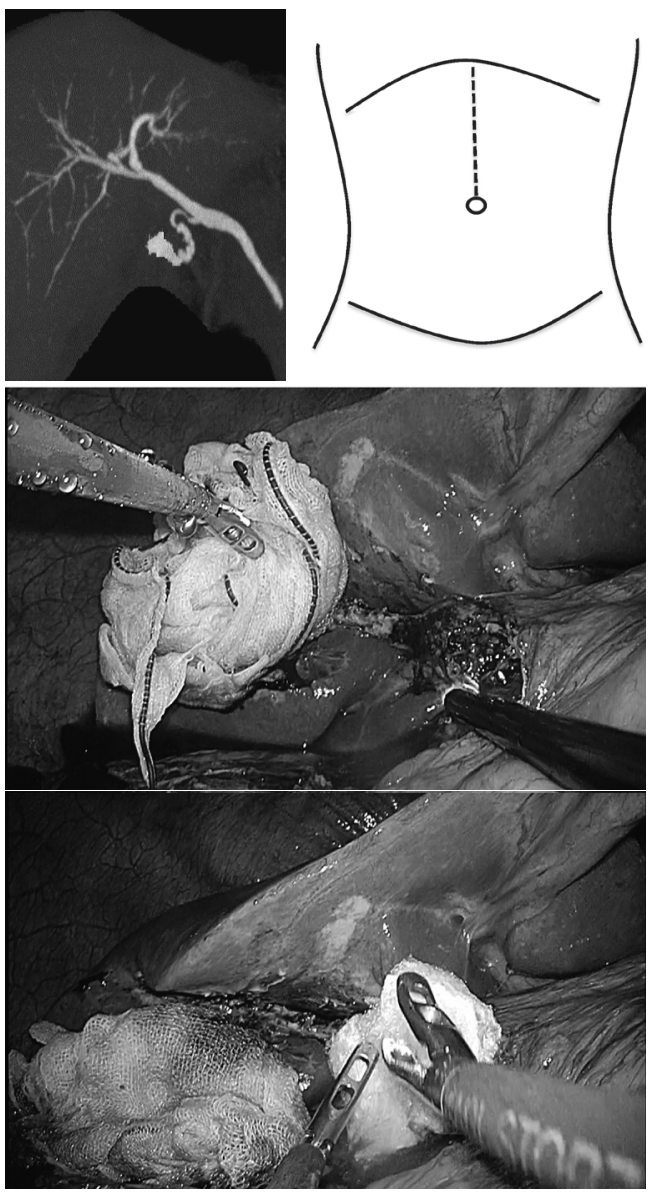

Fig. 3a：DIC-CT所見. 陰性胆囊であるが明らかな 総胆管結石や胆囊管走行異常は認められない.

$\mathrm{b}$ ：臍を右に避ける上腹部正中切開創を有して いた

$\mathrm{c}$ ：胆囊動脈損傷により出血をきたしたが，ガ 一ゼ圧迫により一時止血を行い胆囊摘出後にアル ゴンビーム凝固にて止血を施行.

$\mathrm{d}$ ：胆囊動脈損傷部に止血剤を塗布した.

$$
\frac{\mathrm{a} \mid \mathrm{b}}{\mathrm{c}}
$$

て $20 \mathrm{~mm}$ 弱の結石を数個認めた. DIC-CTでは総胆管 結石および胆囊管の分岐異常は認めなかった（Fig. 2a).

手術所見 : 臍を左に避ける中腹部正中切開創を有し ていた（Fig. $2 b)$ ）臍部に約 $2.5 \mathrm{~cm}$ の縦切開を置き小 開腹した，臍直下の癒着を直視下に剥離しEZアクセ スを装着した。腹壁に癒着した大網と横行結腸を超音 波凝固切開装置で剥離し胆囊底部を露出した。胆囊の
炎症は軽度で順行性に胆囊を摘出した。手術時間は69 分, 出血量は少量であった (Fig. 2c, d).

術後経過：術後 5 日目に軽快退院した.

症例 $3: 75$ 歳, 男性.

主訴 : 右季肋部痛.

既往歴：30歳台に胃潰瘍に対し, 開腹幽門側胃切除 B- I 再建を施行されていた。

家族歴：特記事項なし。

現病歴：食後に右季肋部を自覚するようになり，近 医を受診した，腹部エコー検査にて胆囊結石が指摘さ れ，当院紹介受診となった。

初診時現症 : 身長 $156 \mathrm{~cm}$, 体重 $44 \mathrm{~kg}$. 腹部は平坦・ 軟で，右季肋部に圧痛を認めた。

検査所見：血液生化学検查では, 著明な炎症反応の 上昇を認めたが肝胆道系酵素の上昇は軽度であった。 WBC $12,260 \times 10^{3} \mu \mathrm{L}$, AST $61 \mathrm{U} / \mathrm{L}$, ALT $42 \mathrm{U} / \mathrm{L}$, ALP 323U/L, $\gamma$-GTP 69U/L, 総ビリルビン $0.95 \mathrm{mg}$ $/ \mathrm{dl}, \mathrm{CRP} 26.50 \mathrm{mg} / \mathrm{dl}$ であった．腹部超音波検査・腹 部 CT 検査にて胆囊壁の浮腫状肥厚と内腔に胆泥の貯 留, 胆囊頸部に $26 \mathrm{~mm}$ 大の結石の嵌頓を認めた. DIC-CTでは陰性胆囊であったが，総胆管結石や胆囊 管の分岐異常は認めなかった（Fig. 3a）.

手術所見：臍を右に避ける上腹部正中切開創を有し ていた（Fig. 3b)，臍部および創直下の癒着は認めな かった。胆囊底部と横行結腸, 十二指腸が癒着してお り，これらを剥離し胆囊の全貌を露出した，胆囊壁は 全体に肥厚しており, 特に胆囊頸部の炎症が高度であ った。胆囊底部から順行性に剥離を進めていたが, Calot三角部の炎症が高度でcritical viewが得られず 剥離の途中で胆囊動脈を損傷した。出血部の圧迫およ び出血点の確認のためマルチチャンネルポートからガ 一ゼを複数回出し入れし, 視野の確保と出血点の視認 をした上でクリッピングおよびアルゴンプラズマ凝固 にて止血し胆囊を摘出した。最後に止血剤を撒布し手 術を終了した (Fig. 3c, d). 手術時間は111分, 出血 量は50gであった。

術後経過：術後 7 日目に軽快退院した.

$$
\text { 考察 }
$$

LC は内視鏡手術の黎明期から存在した術式であり， 現在では胆囊摘出における標準術式となっている。さ らに, 低侵襲性と整容性の向上を実現するためにポー トの数やサイズを減らした術式が考案され，現在では 総称して reduced port surgeryと呼ばれてきてい る2)3)．RPSの歴史を紐解くと，1996年にGangerらが 


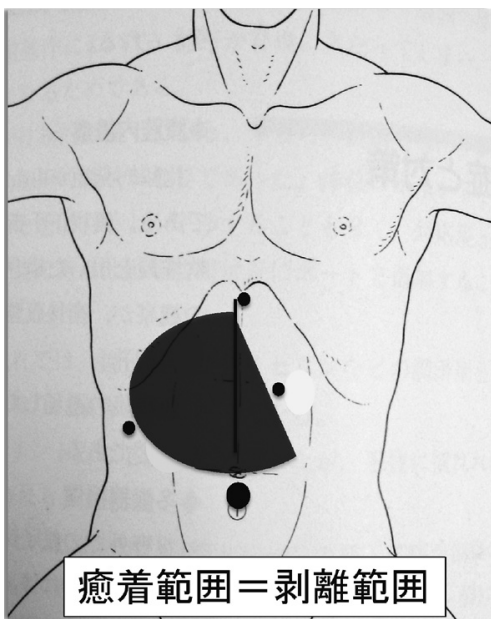

従来法および 細径法 (4ポート)

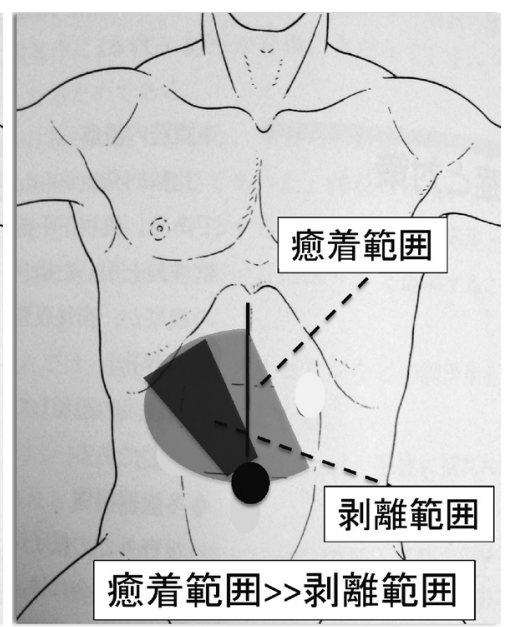

単孔法

Fig. 4 : 上腹部手術既症例における癒着範囲と従来法および細径法もしくは単孔 法での剥離範囲の違い。従来法および細径法の場合は癒着範囲と同程度の剥離 範囲が必要であるが, 単孔法の場合は必要最小限の剥離で目的臟器に到達する ことができる。

needlescopic surgeryを提唱4)したのが始まりであり， 単孔式手術はNavarraらが1997年にSILCを初めて報 告5)している。.これらの報告を受け，本邦においても RPSの普及が広まってきている. 日本内視鏡外科学会 での第13回集計結果報告によると単孔式腹腔鏡下手術 の総手術件数 52,838 例中, 胆囊摘出術が 27,552 例と最 も多く, 次いで虫垂切除術, 鼠径ヘルニア根治術, 大 腸切除術の順に臨床応用されている ${ }^{1)}$.

単孔式腹腔鏡下胆囊摘出術は臍からスコープや複数 鉗子を挿入するため, 機器同士の干渉が起こりやすく 手術難度が高くなるため, 純粋な単孔法というょりポ 一トの径を縮小し細径鉗子を用いた細径法や, 単孔法 と細径法を複合した方法などを採用している施設や報 告が多く見受けられる ${ }^{677)}$. RPSに期待される利点は, 術後疼痛の軽減と整容性の向上である. 純粋な単孔法 の創は臍部のみとなるため, 整容性に関しては非常に 良好とされている ${ }^{8) 9}$ が, 術後疼痛に関しては単孔法, 細径法ともに一定の見解は得られていない10) 16). 細 径法は従来の腹腔鏡手術とほぼ同様の手術操作が行え るが, 細径針子の剛性やジョーの形状制限などに問題 がある. 一方, 単孔法はスコープと鉗子同士との干渉 を回避するための独特の手技の熟練が必要である.
筆者らは, 良性胆囊疾患における腹腔鏡下胆囊摘出 術は急性胆囊炎症例や開腹手術既往例においても，ま ずは臍創部一つのみの純粋なSILCを第一選択として 採用している．医学中央雑誌で「単孔式腹腔鏡下胆囊 摘出術」「手術既往」「胆囊結石」のキーワードを用い て1996年〜2017年の間で検索したところ，会議録を除 き 1 例の報告があった ${ }^{17)}$. 術中において, 炎症や癒着 の程度によりポートは適宜追加し安全に施行できるよ う努めている.さらに, 開腹手術への移行は迅速にで きるよう準備を整え手術に臨んでいる.

腹腔内癒着症例や高度炎症を伴った胆囊炎に対する SILCのメリットを 3 例の経験をもとに考察した。ま ず, 既往の開腹手術により臍直下に癒着を認める場合, 直視下に癒着剥離が可能であることである，従来のス コープや細径スコープを挿入するアクセスポートを作 成する場合は直視下での剥離は困難であり, 術前に癒 着の有無を検索した上で至適な部位に作成することが 多い. SILCでは臍に $25 \mathrm{~mm}$ 程度の切開を置くため, 臍直下および周囲の癒着があっても直視下に剥離が可 能となる.マルチチャンネルポートが装着できれば, 癒着があっても気腹圧によって均一に腹壁が挙上さ れ, 臟器には重力によるカウンタートラクションがか 
かるため腹壁癒着部の剥離層はより明瞭となる。さら に，すぐさま同部からの 2 本の鉗子とスコープの扦入 により腹腔内の癒着剥離が可能となり，目標となる臓 器に対し必要最小限の剥離でワーキングスペースを確 保することができる。一方，従来法や細径法は多方向 から鉗子挿入が必要であるため, より広範囲な癒着剥 離が必要となる (Fig. 4). 加えて, 胆囊炎症例での 胆囊の把持や展開に細径鉗子では剛性が耐えられない 場面においても，単孔法の場合は従来の腹腔鏡用鉗子 を用いるので，ある程度の応用が効く点でも優れてい る. 最後に，出血時などのガーゼの出し入れは， RPS の場合は臍部からの挿入に限られる。単孔法の場合は マルチチャンネルポートの脱着により，ガーゼや止血 剂の出し入れが細径法より容易に行え，緊急時への対 応にも優れているといえよう。

\section{結語}

手術既往症例や胆囊炎症例の胆囊摘出術においては 安全性を最優先にアプローチ法を考慮することは言う までもないが, SILCは癒着剥離や出血時の対応など 従来法や細径法と比較しても有用性があり，これらの メリットを踏まえた上でSILCを術式選択の一つとし て考慮しても良いのではないかと考えられた.

利益相反：なし

\section{文献}

1）日本内視鏡外科学会 : 内視鏡外科手術に関するア ンケート調査一第13回集計結果報告一。日内視鏡 外会誌 $2016 ; 21 ： 660-671$

2) John PH, Thanakumar J, Krishnan A, et al : Reduced port laparoscopic repair of Bochdalek hernia in an adult: Afirst report. J Minim Access Surg $2012 ; 8: 158-160$

3) Kodera Y : Reduced port surgery for gastric cancer : another giant leap for mankind? Gastric Cancer $2013 ; 16: 457-459$

4) Gagner M, Garcia-Ruiz A : Technical aspects of minimally invasive abdominal surgery performed with needlescopic instruments. Surg Laparosc Endosc 1998; 8 : 171-179

5) Navarra G, Pozza E, Occhionorellis S, et al: One-wound laparoscopic cholecystectomy. Br J Surg $1997 ; 84: 695$

6) 武政伊知朗：単孔式手術と Reduced Port Surgery : 消化器外科学レビュー. 総合医学社, 東京,
2015, p159- 163

7）森 俊幸, 得津敬之, 杉山政則：消化器外科 Reduced Port Surgeryの現況と課題（解説）Annual Review消化器. 中外医学社, 東京, 2014, p278- 283

8）高 賢樹, 山田成寿, 柳田 剛他：腹腔鏡下胆囊 摘出術における reduced port surgeryの整容性に 対する満足度調査. 日臨外会誌 $2014 ; 75 ： 2679$ $-2686$

9) Lai EC, Yang GP, Tang CN, et al : Prospective randomized comparative study of single incision laparoscopic cholecystectomy versus conventional four-port laparoscopic cholecystectomy. Am J Surg $2011 ; 202: 254-258$

10) Marks J, Tacchino R, Roberts $K$, et al : Prospective randomized controlled trial of traditional laparoscopic cholecystectomy versus single-incision laparoscopic cholecystectomy : report of preliminary data. Am J Surg 2011 ; 201 : 369 373

11) Tsimoyiannis EC, Tsimogiannis KE, Pappas-Gogos G, et al : Different pain scores in single transumbilical incision laparoscopic cholecystectomy versus classic laparoscopic cholecystectomy : a randomized controlled trial. Surg Endosc 2010 ; $24: 1842-1848$

12) Bucher P, Pugin F, Buchs NC, et al : Randomized clinical trial of laparoscopic single-site versus conventional laparoscopic cholecystectomy. Br J Surg $2011 ; 98: 1695-1702$

13) Ma J, Cassera MA, Spaun GO, et al : Randomized controlled trial comparing single-port laparoscopic cholecystectomy and four-port laparoscopic cholecystectomy. Ann Surg $2011 ; 254$ : $22-27$

14) Phillips MS, Marks JM, Roberts K, et al : Intermediate results of a prospective randomized controlled trial of traditional four-port laparoscopic cholecystectomy versus single-incision laparoscopic cholecystectomy. Surg Endosc $2012 ; 26$ : $1296-1303$

15) Sajid MS, Khan MA, Ray K, et al : Needlescopic versus laparoscopic cholecystectomy : a metaanalysis. ANZ J Surg $2009 ; 79$ : $437-442$ 
16) Bisgaard T, Klarskov B, Trap R, et al : Pain after microlaparoscopic cholecystectomy. A randomized double-blind controlled study. Surg Endosc $2000 ; 14: 340-344$
17）斉藤一幸, 多賀美信美, 立岡哲平他 : 上腹部手術既 往のある急性胆囊炎に対して緊急単孔式腹腔鏡下 胆囊摘出術を施行し得た 1 例. 日腹部救急医会誌 $2015 ; 35: 921-924$

\title{
THREE CASES OF CHOLELITHIASIS WITH PREVIOUS ABDOMINAL SURGERY PERFORMED SINGLE INCISION LAPAROSCOPIC CHOLECYSTECTOMY
}

\author{
Yoshimasa SHIMIZU, Kazumitsu SUZUKI, Takatoshi SEKI, Yosuke OZAWA, \\ Nobuo TACHIKAWA and Tomoo SHATARI \\ Department of General Surgery, Mito Red Cross Hospital
}

We have performed single incision laparoscopic cholecystectomy for three cases of cholelithiasis with previous histories of abdominal surgeries. Their previous surgeries included gastrectomy under laparotomy, Cesarean section and appendectomy in Case 1 ; laparoscopic ileocecal resection for Crohn disease and laparoscopic dissection of adhesions with partial enterectomy for ileus in Case 2 ; and gastrectomy under laparotomy in Case 3. Extensive adhesions were confirmed in the periumbilical area and the upper abdomen in Case 1 and 2. We performed dissection of the periumbilical adhesions under direct vision and placement of a multichannel port, followed by laparoscopic dissection of adhesions in the upper abdomen and around the gallbladder to remove the gallbladder. In Case 3, intraoperative injury of the cystic artery caused hemorrhage, for which rapid taking out and putting in of gauzes through the periumbilical port enabled us to see the bleeding point directly, leading to successful hemostasis.

Compared to the conventional or needlescopic cholecystectomy, the single incision laparoscopic cholecystectomy demands a high degree of technical difficulty. However, we consider the method to be excellent, because it can dissect periumbilical adhesions under direct vision and it can reach at the gallbladder in the minimal dissecting areas. And if emergency complications such as bleeding may occur, easy taking out and putting off gauzes as well as hemostatic agent can be done by getting on and off the port, showing a superiority even in emergency situations.

Key words : single incision laparoscopic cholecystectomy, previous abdominal surgery, cholelithiasis 